\title{
HUBUNGAN ETNIS JAWA DAN TIONGHOA DALAM NOVEL TUNGGAK-TUNGGAK JATI
}

\author{
Yulitin Sungkowati \\ Balai Bahasa Surabaya
}

\begin{abstract}
This article tries to explore the relationship between Javanese and Chinese ethnic groups in Tunggak-Tunggak Jati, a Javanese novel by Esmiet. The novel describes the older Javanese generation' views of the Chinese ethnic group and vice versa based on prejudice and stereotype. But the younger Javanese and Chinese generations try to eradicate the prejudice and ethnic partition. The young Chinese generation's consciousness that Indonesia is their country results in the feeling that they are not different from the Javanese ethnic group and they are not strangers in Indonesia. The young Javanese generation also tries to accept the Chinese ethnic group as part of Indonesia. This novel also shows that the Javanese and Chinese ethnic groups need each other in social interaction to establish true relationship and to respect each other through, for example, marriage.
\end{abstract}

Keywords: relationship, ethnic group, Javanese, Chinese

\section{A. PENDAHULUAN}

Dalam perjalanan sejarahnya, sejak kolonialisme Belanda sampai era kemerdekaan, etnis Tionghoa sering kali menjadi sasaran tindak kekerasan, baik berupa perusakan, pembakaran, penjarahan maupun pembunuhan, seperti terjadi di Batavia tahun 1740, pembunuhan oleh Pangeran Adipati Cakraningrat IV di Pesisir Utara Jawa, pada masa Perang Jawa tahun 1825-1830, penjarahan di Kudus tahun 1918, dan pembunuhan masal tahun 1946-1948. Pada masa Orde Baru, berbagai peraturan diskriminatif diberlakukan pada etnis Tionghoa, seperti penggantian sebutan Tionghoa menjadi Cina, pelarangan perayaan agama, kepercayaan, dan adat istiadat secara terbuka, penggantian nama berbau Cina, dan pelarangan penggunaan bahasa Cina. Etnis Tionghoa hanya diberi ruang untuk berbisnis hingga muncul beberapa konglomerat yang menjalin kolusi dan menjadi kroni penguasa. Hal itu menimbulkan stereotip negatif seolaholah semua etnis Tionghoa adalah makhluk ekonomi yang tidak bermoral (Setiono, 2002). Oleh karena itu, aksi kekerasan terhadap etnis
Tionghoa di Pulau Jawa pada masa Orde Baru meningkat dan mencapai puncaknya pada kerusuhan di Jakarta tanggal 13-14 Mei 1998.

Tragedi kemanusiaan tersebut telah mengubah citra Indonesia sebagai bangsa yang ramah, santun, dan toleran menjadi berwajah beringas dan penuh kebencian hingga mendorong banyak kalangan melakukan refleksi atas hubungan antaretnis di Indonesia, khususnya antara etnis Tionghoa yang oleh etnis non-Tionghoa diklaim sebagai nonpribumi dengan etnis yang mengklaim diri sebagai pribumi. Dalam bidang politik, beberapa peraturan yang dinilai diskrimintif pun dihapuskan atau dicabut, seperti istilah pribumi dan nonpribumi oleh Presiden BJ. Habibie melalui Instruksi Presiden No. 26/1998 tanggal 16 September, Instruksi Presiden No 14/1967 tentang Agama, Kepercayaan, dan Adat Istiadat Cina oleh Presiden Abdurahman Wahid melalui Keputusan Presiden No. 6/2000, dan larangan penggunaan bahasa Tionghoa. Selanjutnya, hari raya Imlek ditetapkan sebagai hari libur fakultatif melalui keputusan Menteri Agama No. 13/2001. 
Seiring dengan terbukanya pintu kebebasan di bidang politik, para pekerja sastra tidak melewatkan momentum berharga itu begitu saja. Pemerhati sastra Tionghoa bekerja sama dengan Kepustakaan Populer Gramedia menerbitkan kembali karya-karya sastra Melayu Tionghoa yang sangat kaya, baik dari segi isi, jumlah karya yang dihasilkan, maupun jumlah pengarang yang terlibat di dalamnya. Di samping untuk menunjukkan peran etnis Tionghoa dalam dunia sastra Indonesia agar diakui sebagai bagian integral bangsa Indonesia, penerbitan itu juga untuk menunjukkan kepedulian pengarangpengarang Tionghoa atas berbagai masalah sosial, politik, dan budaya yang terjadi di Indonesia sebelum dan pada awal kemerdekaan (2000:18). Joe Lan (1962:119) telah lama menunjukkan bahwa tidak sedikit karya sastra peranakan Tionghoa yang telah menunjukkan spirit kebangsaan Indonesia, menunjukkan kesadarannya sebagai bagian dari bangsa Indonesia melalui cerita-cerita yang ditulisnya. Oleh karena itu, suatu kerugian besar bagi bangsa Indonesia jika karya-karya mereka tidak diakui dan dibiarkan hilang begitu saja.

Claudine Salmon (1985:60, 1999:365) mengungkap kepedulian dan keingintahuan penulis-penulis keturunan Tionghoa terhadap masyarakat pribumi melalui karya-karyanya yang sekaligus juga memperlihatkan adanya hubungan yang cukup erat di antara mereka. Ketertarikan dan penghayatannya atas berbagai etnis di Indonesia dibuktikan dengan karyakaryanya yang bernuansa etnografis, perkawinan antaretnis, dan pembauran. Lie Kim Hoo menulis cerpen Anjasari (1929) menceritakan masyarakat Tengger Jawa Timur, Gandroeng (1929) mengungkap penari gandrung Banyuwangi dan Bali, Oedjoeng (1932) menceritakan ritual ujung masyarakat Tengger, Dewa Poetih (1932) mengungkap budaya masyarakat Badui Dalam, roman Brangti (1934) berlatar Bali Aga, dan roman Gowok (1936) yang mengungkap salah satu kebiasaan masyarakat Jawa Kuna di daerah Banyumas. Soe Lie Piet menulis roman Lejak (1935) yang bercerita tentang masyarakat Bali dan Njoo Cheong Seng menulis roman berlatar masyarakat Irian dengan judul Tjinggalabi Aoeah, Papoeasche Zenden Romans 'Kembalilah, Sebuah Roman tentang Adat Istiadat Irian'. Karya-karya Lie Kim Hoo itu merupakan sebuah upaya pencarian nilai-nilai kehidupan yang luhur dari budaya masyarakat lokal di Indonesia sebagai reaksi terhadap makin besarnya pengaruh cara hidup Eropa yang menimbulkan ketidaktenteraman. Menurutnya, masyarakat lokal ternyata memiliki dan memelihara keseimbangan hubungan sosialnya dengan baik sehingga relatif tidak terpengaruh budaya Barat (Salmon, 1985: 103, 1999:363-373).

Hubungan antaretnis Tionghoa dengan penduduk pribumi dengan berbagai hambatan lingkungan sosial yang harus dihadapi oleh kedua belah pihak serta perkawinan antaretnis dengan kadar optimisme yang berbeda juga tidak luput dari perhatian mereka, antara lain tampak dalam Njai Soemirah (1917) karya Thio Tjin Boen, Njai Aisah (1915) karya Tan Boen Kim, Peniti Dasi Barlian (1922) karya Tan Tjin Kang, Njai Marsina (1923) karya Numa, dan Bunga Roos dari Tjikembang (1927) karya Kwee Tek Hoay (Salmon, 1985:60). Dalam sastra Jawa, peran etnis Tionghoa juga tidak kecil. Penerbit Tan Khoen Swie (1905) di Kediri pada masanya merupakan penerbit yang giat menerbitkan dan memasarkan karya-karya sastra berbahasa Jawa, baik berupa terjemahan karya-karya Tiongkok maupun karya-karya sastra Jawa lama yang mengandung ajaran moral. Pada masa sebelum kemerdekaan, pengarang-pengarang Tionghoa juga terlibat dalam penulisan karya sastra Jawa, seperti Tjak Iem, Max Moe, dan Tan Poet, sedangkan sesudah kemerdekaan tercatat nama Kho Ping Hoo yang cukup produktif (Hutomo, 1988:4745)

Berbeda dengan pengarang-pengarang Tionghoa yang sudah menunjukkan ketertarikannya pada persoalan hubungan antaretnis Tionghoa dengan etnis-etnis di Indonesia sejak sebelum kemerdekaan, pengarang sastra Indonesia justru sebaliknya. Hal itu dapat dilihat dari langkanya sastra 
Indonesia yang membicarakannya (Hutomo, 1978, 1988: 32). Di samping mungkin karena faktor ketidaktertarikan, faktor lainnya adalah kurang dikuasainya kehidupan etnis Tionghoa di Indonesia oleh pengarang-pengarang nonTionghoa (Hutomo, 1978). Sebab lainnya adalah represi pemerintah Orde Baru yang mengharamkan masalah yang berkaitan dengan SARA dibicarakan secara terbuka, termasuk dalam karya sastra. Oleh karena itu, gairah merayakan kebebasan dan pluralisme dalam sastra Indonesia baru muncul seiring dengan tumbangnya Orde Baru dan lahirnya Orde Reformasi, antara lain tampak dari lahirnya cerita bersambung Cau Bau Kan karya Remy Silado di harian umum Republika pada tahun 1997 (dibukukan oleh KPG tahun 1999) dan kumpulan cerpen Panggil Aku Peng Hwa (2002) karya Veven Sp.

Penerbitan kembali karya-karya sastra Tionghoa berbahasa Melayu Rendah pada tahun 2000-an oleh KPG itu mungkin tidak hanya didorong oleh keinginan untuk menunjukkan peran dan kontribusi pengarangpengarang Tionghoa dalam sastra Indonesia, tetapi juga agar menjadi bahan kajian untuk melihat hubungan antaretnis di Indonesia pada masa lalu, setidak-tidaknya dari sudut pandang sastra karena karya sastra tidak lahir dari ruang hampa. Sastra adalah produk masyarakatnya sehingga tidak dapat dilepaskan dari kondisi yang melingkunginya (Sumardjo, 1979:12). Ia berada dan hidup di tengah masyarakat serta dilahirkan oleh pengarang sebagai anggota masyarakat berdasarkan desakan-desakan emosional atau rasional tertentu untuk menanggapi keadaan yang sedang atau pernah dilihatnya. Dengan demikian, sastra dapat merupakan potret yang melukiskan masyarakat, analisis sosial yang menyiasati perubahan-perubahan, dan terkadang memberikan landasan penilaian tentang apa yang sedang terjadi (Kuntowijoyo, 1987:145).

Untuk menciptakan sikap saling memahami dalam membangun kembali hubungan antaretnis Tionghoa dan nonTionghoa di Indonesia pada era reformasi ini, karya-karya sastra Melayu Tionghoa yang menyajikan tema-tema pembauran atau hubungan antaretnis dari perspektif pengarang Tionghoa perlu dikaji karena dari karya-karya mereka setidaknya dapat diperoleh gambaran dan diketahui sikap, cara berpikir, cara pandang, dan cara merasakan orang-orang Tionghoa di Indonesia (Hutomo, 1988:32). Karya-karya mereka menggambarkan beragam pandangan dan pikiran (Damono, 1999:219): ada yang masih menganggap Cina sebagai tanah airnya, keinginannya untuk kembali ke negeri asalnya, dan secara tersirat belum dapat menerima etnis pribumi dalam kelompok mereka, tetapi ada yang telah memilih dan menetapkan Indonesia sebagai tanah airnya dan membaur dengan masyarakat pribumi tanpa meninggalkan budayanya.

Dalam kerangka itu, kiranya perlu dibicarakan karya sastra yang ditulis oleh pengarang dari salah satu etnis non-Tionghoa karena persoalan yang jarang diungkap dalam sastra Indonesia itu telah muncul pada sastra Jawa sebelum masa reformasi. Pada tahun 1977, Esmiet, seorang pengarang sastra Jawa dari Banyuwangi, Jawa Timur, telah mengangkat persoalan hubungan etnis Tionghoa dan Jawa dalam novelnya yang berjudul Tunggak-Tunggak Jati (TTJ). Meskipun ditulis dalam bahasa daerah (Jawa), TTJ adalah novel pertama dan pelopor yang ditulis oleh pengarang pribumi yang memaparkan agak mendalam hubungan antara pribumi dan nonpribumi (Hutomo, 1988:3334), masalah yang masih dianggap krusial dan tabu untuk dibicarakan di masa Orde Baru (Widati, 2001:333). TTJ menunjukkan bahwa sastra Jawa modern memiliki keterlibatan sosial yang cukup intensif (Soeprapto, 1993:262) dan telah mengangkat masalah yang dihadapi oleh bangsa Indonesia sebagai bangsa yang multietnis dan multikultur. Novel ini menarik untuk dibicarakan guna melihat bagaimana hubungan antaretnis Jawa dan Tionghoa dilihat dari sudut pandang pengarang Jawa. 


\section{B. STEREOTIP DAN PRASANGKA NEGATIF TERHADAP ETNIS TIONGHOA}

Dalam hubungan sosial, pandang memandang antara satu orang atau satu kelompok dengan kelompok lainnya tidak mungkin dihindari. Bahkan, kualitas hubungan itu sangat ditentukan oleh bagaimana pihakpihak yang terlibat di dalamnya saling melihat dan bersikap. Jika pandangan mereka positif, hubungan akan berjalan dengan baik. Sebaliknya, jika pandangan negatif yang mengemuka, maka tidak tertutup kemungkinan akan timbul masalah dan konflik terbuka.

TTJ tampaknya berusaha mengatasi jarak sosial antaretnis Jawa dan Tionghoa meskipun tidak dapat melepaskan diri dari prasangka-prasangka rasial. Pandangan orang Jawa terhadap etnis Tionghoa atau sebaliknya dalam novel ini dilandasi oleh stereotip tertentu. Kesan adanya kebencian tersembunyi etnis Jawa terhadap etnis Tionghoa dapat dilihat dari sebutan-sebutan yang diberikan oleh orang Jawa terhadap orang Tionghoa, seperti Cina sipit, Cina lemu, Cina gendut, singkek gendheng 'Cina gila', dan babi meteng 'babi hamil'. Sebutan Cina secara tidak langsung menempatkan etnis Tionghoa sebagai bukan orang Jawa atau Indonesia, tetapi orang asing. Etnis Tionghoa diposisikan oleh orang Jawa sebagai kelompok pendatang yang menumpang hidup di bumi Indonesia, khususnya di tanah Jawa. Orang Jawa dalam TTJ menganggap orang-orang Tionghoa suka menghalalkan segala cara dan sombong karena stereotip yang dilekatkan padanya sebagai makhluk ekonomi penumpuk harta dan ekseklusif.

Untuk memuluskan usahanya, Bian Biau digambarkan sangat royal memberi uang kepada penguasa-penguasa dari etnis Jawa di daerah babadan hutan jati. Ia memiliki hak mengelola tanah babadan karena menyuap para mandor dan mantri hutan. Padahal, tanah babadan itu seharusnya diberikan hak pengelolaannya kepada penduduk sekitar hutan dengan bantuan modal dari perhutani guna meningkatkan kesejahteraan dan mencegah pencurian kayu oleh masyarakat setempat.
Bahkan, ia digambarkan mencoba "menjual" anak gadisnya kepada seorang pejabat demi melindungi usaha dan asetnya. Ia, yang semula melarang anaknya, Lien Nio, berpacaran dengan Karmodo kemudian justru memaksanya menikah setelah anak bekas jongosnya itu menjadi pejabat yang membawahi wilayah babadan hutan jati Kalidawir. Tugas memuluskan proyek itu lalu dibebankan pada anak keduanya, Siau Yung, ketika Lien Nio menolak pernikahan "ekonomi"itu.

Bah Ing Hwat, yang memiliki toko terbesar di pasar Kalidawir, juga menggunakan cara serupa untuk mencoba masuk dalam lingkungan penguasa etnis Jawa. Ia memaksa anaknya, Ing Liem, berpacaran dengan Karsini (adik Karmodo) setelah Karmodo menjadi pejabat. Ing Hwat berharap pernikahan anaknya dengan keluarga pejabat dapat memuluskan jalannya untuk ikut menguasai orang-orang Kalidawir guna melancarkan usaha dagangnya. Padahal, Bah Ing Hwat sesungguhnya tidak menyukai etnis Jawa (hlm. 69). Sebelum Karmodo menjadi pejabat, Bah Ing Hwat melarang Ing Liem berpacaran dengan Karsini dan berusaha menjodohkannya dengan anak Bian Biau, Siau Yung, yang sesama Tionghoa totok. Dengan cara-cara seperti itu, etnis Tionghoa digambarkan dapat menguasai urat nadi perekonomian Kalidawir. Stereotip lain yang dilekatkan padanya adalah sombong, kasar, tidak menghargai orang Jawa, dan menempatkan perempuan Jawa pada posisi yang rendah sebagai gundik.

Atas dasar prasangka bahwa orang Tionghoa menempatkan perempuan Jawa hanya sebagai gundik, orang-tua dari kalangan etnis Jawa melarang anak perempuannya berpacaran dengan laki-laki Tionghoa. Stereotip itu telah menimbulkan prasangka negatif yang demikian kuat pada orang tua etnis Jawa bahwa semua laki-laki Tionghoa hanya ingin menjadikan perempuan Jawa sebagai gundiknya. Oleh karena itu, orang tua Karsini melarang anak gadisnya itu berpacaran, apalagi menikah dengan Ing Liem meskipun Ing Liem hendak menikahinya secara resmi, "Arepa janji 
piye wae, jenenge wong Jawa dikawin Cina kuwi nistha, dakomongi. Nistha!" Emboke nggetak ora kalah santak. "Pokoke aku karo bapakmu ora setuju kowe digundhik Cina. Apa maneh masmu." (hlm. 21)' "Mau janji bagaimana pun juga, yang namanya orang Jawa dinikahi Cina itu nista. Nista! Ibunya membentak tidak kalah keras. "Pokoknya aku dan bapakmu tidak setuju kamu digundik Cina. Apalagi kakakmu." '(hlm. 21).

Prasangka itu kemungkinan merupakan warisan era kolonial karena pada masa itu banyak perempuan Indonesia dijadikan nyai atau gundik oleh pedagangpedagang Tionghoa, sebagaimana tampak pada karya sastra Melayu Tionghoa. Nyai adalah perempuan yang dipelihara oleh pejabat kolonial dan pejabat-pejabat swasta Belanda yang kaya serta pedagang-pedagang Asia (Christanty, 1994). Karena para pendatang Eropa dan Asia datang ke Indonesia tanpa disertai istri, mereka mengambil perempuan setempat sebagai istri tidak resmi atau peliharaan yang dapat ditinggalkan sewaktuwaktu. Dengan demikian, nyai atau gundik merupakan sebuah posisi yang sangat merendahkan perempuan pribumi meskipun dari sisi materi mungkin menguntungkan. Sementara itu, stereotip etnis Tionghoa sebagai makhluk ekonomi barangkali dapat dilihat akarnya yang menguat pada era Orde Baru. Pada masanya, etnis Tionghoa hanya diberi ruang untuk berbisnis sehingga sebagian dari mereka dapat menguasai perekonomian Indonesia. Walaupun tidak selalu benar, dominasi kelompok etnis Tionghoa dalam sektor ekonomi sering dianggap oleh penduduk pribumi bahwa semua etnis Tionghoa kondisi perekonomiannya lebih baik daripada penduduk pribumi. Secara sosial, sebagian besar penduduk pribumi juga melihat mereka sebagai orang asing meskipun sebagian besar etnis Tionghoa sudah menjadi warga negara Indonesia. Oleh karena itu, kecemburuan sosial dan ekonomi sering dijadikan alasan jika terjadi pertikaian terbuka antara penduduk pribumi dengan kelompok etnis Tionghoa (Faruk, et al, 2000:97).
Pandangan yang menempatkan etnis Tionghoa sebagai orang asing dan diam-diam menumbuhkan kebencian di hati orang-orang Jawa bukan hal yang tiba-tiba saja muncul karena dalam novel ini juga diungkapkan sikap dan pandangan orang-orang Tionghoa terhadap orang-orang Jawa. Mereka menganggap rendah orang Jawa: orang Jawa adalah bangsa jongos, babu, dan kuli. Stereotip ini tidak jauh dari hasil temuan Selo Sumarjan (Sumarto, 1993:143) di Semarang bahwa etnis Tionghoa menganggap dirinya lebih cerdas dan lebih mampu daripada orang Indonesia. Atas dasar stereotip itu, orang tua etnis Tionghoa juga tidak ingin anakanaknya berpacaran dan menikahi perempuan Jawa, kecuali dapat menguntungkan secara ekonomi. Karena kedudukannya yang lebih rendah, laki-laki Tionghoa menempatkan perempuan Jawa hanya sebagai gundik. Ibu Lien Nio, Kartinah, adalah perempuan Jawa, tetapi tidak dijelaskan bagaimana posisinya di hadapan Bian Biau, sebagai istri sah atau gundik? Ia hanya disebutkan berasal dari daerah Parijatah yang dikenal sebagai daerah yang perempuan-perempuannya dapat "dibeli". Jadi, tampaknya Kartinah hanya dijadikan gundik oleh Bian Biau dan hubungan dengan keluarganya pun diputus. Selanjutnya, ia melarang anak gadisnya berpacaran dengan lelaki Jawa. Hal serupa tampak pada Bah Ing Hwat yang melarang Ing Liem berhubungan dengan perempuan Jawa bernama Karsini. Sebagaimana Bian Biau, Ing Hwat juga ingin anaknya menikah dengan sesama orang Tionghoa karena menganggap orang Jawa lebih rendah kelasnya. Oleh karena itu, Bian Biau dan Ing Hwat berusaha menjodohkan anak mereka, yaitu Siau Yung dengan Ing Liem. Bagi Ing Hwat dan Bian Biau, menikahkan anak mereka dengan anak orang Jawa akan mendatangkan malu di lingkungannya karena dalam pandangan mereka orang Jawa selamanya hanya pantas menjadi jongos, kuli, atau babu.

Sikap negatif orang Jawa terhadap orang Tionghoa atau sebaliknya tidak hanya membentangkan jarak sosial yang cukup jauh, tetapi juga menyimpan potensi konflik yang cukup besar. Pada tataran permukaan, 
tampaknya mereka berhubungan baik, tetapi di dalamnya tersembunyi kebencian dan rasa saling curiga. Suami istri Karsonto, yang menjadi jongos di rumah keluarga Tan Bian Biau selama tiga puluh tahun, diam-diam menyimpan dendam dan kebencian karena perlakuan Bian Biau yang sering menghina dan merendahkan orang Jawa. Karsonto dan istrinya merasa seharusnya orang Jawa yang menjadi majikan atau menjadi tuan rumah di tanahnya, bukan kaum pendatang atau orang asing. Baginya, orang Tionghoa tetap orang asing meskipun mereka sudah menjadi warga negara Indonesia karena sikap mereka yang dianggap sombong dan tidak mau berbaur dengan orang Jawa. Harga diri suami istri Karsonto terpaksa ditekan dan dipendam karena mereka tidak berdaya secara ekonomi di hadapan Bian Biau. Kebencian itu baru tampak setelah Karsonto sekeluarga tidak lagi menjadi jongos lantaran anaknya, yang pernah diusir Bian Biau karena berpancaran dengan Lien Nio, menjadi pejabat. Mereka melarang anakanaknya berhubungan dengan etnis Tionghoa. Perasaan itu tampak menurun dan menguasai Karmodo sehingga ketika menjadi pejabat, hal pertama yang dilakukannya adalah mewujudkan keinginannya yang lama terpendam, yakni membalikan keadaan yang menurutnya tidak adil. Sebagaimana orang tuanya, Karmodo menganggap bahwa seharusnya orang Jawa yang menjadi tuan rumah di negeri sendiri, menjadi majikan, bukan jongos, babu, atau kuli yang harus melayani orang-orang Tionghoa (orang asing). Menurutnya, jika orang Tionghoa sudah menjadi warga negara Indonesia, mereka harus menunjukkan sikap sebagaimana orang Indonesia, yaitu menghargai dan tidak memandang rendah orang Jawa (hlm. 21).

Permusuhan tersembunyi itu, tampaknya merupakan gambaran persoalan yang juga ada di dalam masyarakat Indonesia yang bila dirunut ke belakang mungkin dapat ditemukan akar penyebabnya dari politik pecah belah Belanda, antara lain dengan penerapan politik identitas. Belanda (Lohanda, 2001:1-2) membagi penduduk Hindia Belanda dalam tiga golongan besar, yaitu orang Eropa (Europeanen), Timur Asing (Vreemde Oosterlingen), dan pribumi (Inlanders). Timur Asing terdiri atas orang-orang Cina, Arab, dan Asia lainnya. Penduduk pribumi ditempatkan pada strata sosial yang paling rendah, di bawah Cina, Arab, dan bangsa Asia lainnya. Politik identitas itu merupakan strategi yang diterapkan penguasa kolonial untuk memecahbelah penduduk jajahan dan menciptakan ketergantungan padanya. Kemungkinan itu diperkuat dengan adanya catatan sejarah bahwa sebelum kedatangan Belanda, sudah ada etnis Tionghoa di Nusantara. Di sepanjang pesisir utara pulau Jawa telah ditemukan koloni-koloni etnis Tionghoa oleh pasukan Kaisar Kubilai Khan dari dinasti Yuan (1280-1367) yang pada tahun 1293 menyerbu Kerajaan Singosari. Etnis Tionghoa yang berasal dari provinsi Hokkian dan pada umumnya pedagang perantara, petani, dan pengrajin itu hidup rukun dan damai dengan penduduk setempat. Banyak anggota pasukan Kubilai Khan akhirnya memilih menetap di pesisir utara Pulau Jawa dan menikah dengan perempuan-perempuan setempat (Setiono, 2002). Perkawinan antaretnis (Carey, 2008:2007) telah melahirkan anak-anak peranakan yang kemudian menciptakan budaya Tionghoa peranakan yang erat pertaliannya dengan dunia Islam Jawa.

Kecurigaan dan permusuhan tersembunyi antardua etnis itu di dalam TTJ tidak sampai menimbulkan konflik terbuka karena pengarang juga menghadirkan tokohtokoh yang berupaya mengeliminir prasangkaprasangka negatif itu. Meskipun pengarang TTJ berasal dari etnis Jawa, ia terlihat bersikap cukup adil dalam memandang kedua etnis dengan mengedepankan penghargaan terhadap pluralisme. Spirit yang dibangun pengarang adalah spirit keindonesiaan, atas dasar penghayatan dan kesadarannya bahwa etnis Tionghoa merupakan bagian dari bangsa Indonesia. TTJ juga sudah berbicara dengan semangat heterogenitas: etnis Jawa tidak tunggal, demikian pula etnis Tionghoa sehingga prasangka-prasangka negatif coba digoyahkan dengan pandangan-pandangan yang 
menentangnya.

Stereotip yang menempatkan orang Tionghoa sebagai suka menyuap dan kolusi dengan pejabat atau penguasa disandingkan dengan Lien Nio yang tidak setuju dengan cara berbisnis yang menghalalkan segala cara. Stereotip yang menempatkan etnis Tionghoa sebagai orang-orang ekseklusif dan merendahkan orang Jawa juga disandingkan dengan sosok Ing Liem dan Lien Nio yang ingin mengubah cara pandang kelompok etnisnya terhadap etnis Jawa. Ing Liem ingin orangorang Tionghoa tidak mengekseklusifkan diri, tidak mau berbaur dengan etnis-etnis lain, dan merasa sebagai golongan yang lebih tinggi kelas dan kedudukan sosialnya. “....aku isih panggahngugemi janjiku biyen. Kepengin melu ngowahi sikepe bangsaku sing melu nunut urip ing bumi Indonesia kene.” (hlm. 23) '“....aku masih tetap memegang janjiku dulu. Ingin ikut mengubah sikap bangsaku yang ikut numpang hidup di bumi Indonesia."

Pada sisi etnis Jawa, di samping menghadirkan sosok Karmodo yang jujur, novel ini juga memperlihatkan penguasapenguasa Jawa yang pragmatis dan oportunis, seperti Mujahit, Lauri, Kastam, dan Suwarji. Bian Biau dapat menguasai tanah babadan karena diberi kesempatan oleh mandor Mujahit yang telah banyak menerima uang darinya. Lauri, seorang mandor tanam yang dikenal orang banyak menangkap pencuri kayu di hutan, ternyata menjadi pengepul kayu curian dan banyak menerima uang dari Bian Biau. Mantri Suwarji juga digambarkan berperangai buruk. Di samping mudah disuap, ia dikenal sebagai orang yang rakus dan suka main perempuan. Sebagai mantri hutan, seharusnya ia memberikan tanah babadan kepada penduduk sekitar hutan untuk mengelolanya, tetapi ia malah menyewakannya kepada pengusaha Tionghoa. Artinya, kebiasaan menyuap dan berkolusi yang dijadikan stereotip etnis Tionghoa dapat terjadi karena banyak pejabat atau penguasa dari etnis Jawa yang tidak jujur dan mudah disuap. Jika orang Jawa tidak ada yang berperilaku tidak terpuji, tidak memberi peluang untuk disuap dan diajak kolusi, maka orang-orang Tionghoa tidak akan mendapat kesempatan atau peluang menyuap dan mengajak kolusi. Dalam konteks masyarakat Indonesia, gambaran itu mungkin dapat memberi rasa keadilan kepada etnis Tionghoa yang merasa selalu disalahkan dalam setiap kasus suap yang melibatkannya, seperti kasus ambruknya ekonomi Indonesia karena sistem ekonomi yang berpusat pada segelintir orang (konglomerasi), masyarakat dianggap cenderung menyalahkan etnis Tionghoa, tetapi tidak menyalahkan penguasa non-Tionghoa waktu itu yang membuat kebijakan yang melahirkan konglomerasi (Ardan, 2002).

\section{KETERGANTUNGAN SOSIAL DAN EKONOMI}

Keputusan Karmodo untuk membalikkan keadaan, menempatkan etnis Jawa sebagai tuan rumah di negeri sendiri dengan cara mengambil paksa hak pengelolaan atas tanah babadan milik pengusaha Tionghoa (Bian Biau) membuka mata betapa tidak mudahnya hal itu dilakukan. Ia membolehkan Tan Bian Biau tetap menyewa tanah babadan untuk tanaman kacang yang akan diekspor ke Jepang dengan syarat semua pengelolaannya harus dikerjakan sendiri mulai dari membabat dan membersihkan hutan, menanam, menyiangi hingga memanen, tidak boleh mempekerjakan orang-orang Jawa karena sudah lama mereka hanya dijadikan jongos di negerinya sendiri (hlm. 73). Dengan membuat persyaratan seperti itu, Karmodo ingin memberi pelajaran pada Bian Biau agar tidak memandang rendah orang Jawa karena tanpa bantuan orang Jawa, roda usahanya tidak akan berputar. Bagaimana pun juga, Bian Biau tetap tergantung dan membutuhkan orang-orang Jawa sehingga tidak seharusnya bersikap merendahkan dan tidak adil padanya.

Karmodo memang dapat menyadarkan Bian Biau bahwa ternyata tidak semua pejabat Jawa dapat "dibeli" atau disuap dan bahwa ia tidak berarti apa-apa tanpa bantuan orang Jawa, tetapi di sisi lain ia juga melihat bahwa persoalan tidak sesederhana seperti yang dibayangkan. Tindakannya memutus sumber 
ekonomi Tionghoa ternyata juga menimbulkan efek domino, yakni kegoncangan ekonomi masyarakat Kalidawir, terutama pada level bawah yang sangat tergantung perekonomian pada orang-orang Tionghoa. Ia dihadapkan pada kenyataan bahwa masih sangat banyak orang Jawa yang tergantung secara ekonomi pada etnis Tionghoa. Tidak hanya etnis Tionghoa yang membutuhkan bantuan tenaga orang-orang Jawa untuk menggerakan roda usahanya, orang Jawa juga banyak yang menggantungkan kelangsungan hidupnya pada orang Tionghoa. Bahkan, hubungan yang terjalin antara Bian Biau dengan para buruh tani di daerah babadan tidak sekadar hubungan ekonomi semata, tetapi sudah terjalin hubungan sosial yang baik, seperti kebiasaan Bian Biau memberi hadiah lebaran dan kemudahan dalam meminjam uang yang sudah dirasakan oleh warga. Masyarakat di tingkat bawah, para buruh tani di daerah Kalidawir tidak peduli dengan harga diri, gengsi, serta persoalanpersoalan di luar kebutuhan riilnya sehari-hari. Lagi pula, mereka juga punya pandangan sendiri yang berbeda dengan pandangan penguasa seperti Karmodo dalam memandang etnis Tionghoa (hlm. 21).

Pandangan para buruh tani di sekitar hutan tersebut barangkali dapat memberikan gambaran bahwa ada kemungkinan di tingkat akar rumput masyarakat lebih terbuka dalam menerima kehadiran etnis Tionghoa sebagai mitra kerja sama yang saling menguntungkan sehingga tidak dipandang secara negatif dan sebagai ancaman. Banyak buruh di sekitar daerah babadan yang menggantungkan hidupnya pada tanah garapan Bian Biau sehingga ketika hak sewanya diambil, mereka menjadi gelisah karena kehilangan pekerjaan dan mata pencaharian. Oleh karena itu, buruh tani yang kehilangan pekerjaan justru menganggap Karmodolah yang jahat karena telah merampas sumber kehidupan mereka. Niat Karmodo yang ingin membela orang Jawa agar menjadi majikan di negerinya sendiri harus menelan pil pahit karena orang-orang justru bersimpati pada Bian Biau.
"Kebangetan pancen, pak insinyur kuwi. Lha wong tuku babatan dhuwitdhuwite dhewe, kok diprosa kaya ngono. Dupeh kuwasa wae!"

Ana saweneh sing gumreneng.

"Mangka wis akeh ya, pitulungane Bian Biau marang awake dhewe."

"Wihh, iya banget no. Coba, ing jaman wereng kaya ngene iki, saupama ora ana Bian Biau, awake dhewe mangan apa? Sasat angger menit, waton awake dhewe gelem ngrumati tandurane ing babatan, waton awake dhewe gelem ngedol gantasan, yen awake dhewe butuh dhuwit ora tau ditolak." (hlm.91-92).

"Memang keterlaluan, Pak insinyur itu. Orang membeli babadan pakai uang sendiri, kok diambil paksa begitu. Mentang-mentang berkuasa!"

Ada seorang yang menggumam.

"Padahal sudah banyak pertolongan Bian Biau pada kita."

"Wihh, iya. Coba, di zaman wereng seperti ini, seumpama tidak ada Bian Biau, kita makan apa? Ibaratnya setiap menit, asalkan kita mau merawat tanamannya di babadan, asalkan kita mau menjual gantasan, kalau kita butuh uang tidak pernah ditolak." (hlm.91-92).

Gambaran dalam TTJ ini tampaknya juga tidak jauh berbeda dengan apa yang terjadi pada masyarakat Indonesia berkaitan dengan masalah ekonomi dan etnis Tionghoa, seperti dalam kasus penerapan PP 10 tahun 1959 yang melarang orang asing (pada umumnya etnis Tionghoa) berdagang eceran di luar provinsi dan kabupaten dengan maksud untuk melindungi pedagang-pedagang lokal ternyata berdampak luas pada tersendatnya distribusi barang yang akhirnya menjadi salah satu sebab keterpurukan ekonomi Indonesia menjelang tahun 1965 dan kasus kerusuhan Mei 1998 yang mendorong ribuan etnis Tionghoa eksodus ke luar negeri ternyata juga sangat berpengaruh 
pada pemulihan ekonomi nasional (Ardan, 2002).

Diakui atau tidak, suka atau tidak suka, keputusan Karmodo untuk memotong sumber ekonomi Tionghoa ternyata berdampak luas pada etnis Jawa juga. Oleh karena itu, dengan hasutan para mandor rakus yang kehilangan penghasilan ilegalnya, orang-orang Desa Kalidawir justru menyerbu dan mendemo Karmodo ke rumahnya hingga nyaris terjadi kerusuhan. Konflik terbuka terjadi bukan antara etnis Tionghoa dan Jawa, tetapi sesama orang Jawa yang kehilangan pekerjaan dan penghasilan. Janji Karmodo untuk memberikan pengelolaan tanah babadan itu secara gratis kepada masyarakat sekitar hutan tidak dapat diterima oleh orang-orang karena yang mereka butuhkan adalah pekerjaan, bukan janji. Bagi mereka, Bian Biaulah yang secara nyata telah memberi tanah garapan dan membantu ekonominya. Oleh karena itu, mereka digambarkan baru menghentikan rencana aksi anarkisnya setelah Yuk Lin Nio menyuruh mereka bubar. Tanpa campur tangan Lien Nio sebagai ahli waris Bian Biau, Karmodo mungkin sudah menjadi korban amuk masa orang-orang yang ingin dibelanya. "Pancen mung aku ahli warise Papah. Lan mung Papah sing bisa nguwasani atine wong-wong babatan. Sebab sasat urat rosaning ekonomi ing Kalidawir sakubenge mung Papah sing nyekel." (hlm. 97) '"Memang hanya aku ahli waris Papah. Dan cuma papah yang bisa menguasai hati orang-orang babadan. Sebab, ibaratnya urat nadi perokonomian Kalidawir sekitarnya hanya papah yang memegang"'.

Kasus yang menimpa Karmodo memberikan gambaran bahwa keputusan untuk mengambil-alih secara paksa peran ekonomi orang-orang Tionghoa agar orang-orang yang mengklaim diri sebagai pribumi memperoleh apa yang mereka anggap sebagai keadilan, bukanlah keputusan yang realistis dan bijaksana karena banyak orang Jawa yang sudah terlanjur bergantung pada perekonomian mereka dan tidak siap modal untuk mengambilalih dari tangannya. Keadaan itu tampaknya disadari benar oleh pengarang sehingga cara yang ditempuh Karmodo digambarkan tidak berhasil. Cara itu hanya akan menggoncang perekonomian masyarakat secara keseluruhan dan menimbulkan instabilitas (demonstrasi warga yang kehilangan pekerjaan serta orangorang yang punya pandangan lain). Solusi yang ditawarkan pengarang adalah solusi jalan tengah yang alamiah.

\section{P E M B A U R A N M E L A L U I PERKAWINAN DAN PERAN KAUM MUDA}

Jarak sosial yang terbentang karena cara pandang yang didasarkan pada stereotip dan prasangka-prasangka negatif dalam novel ini digambarkan lebih banyak berada pada tingkat orang tua, sedangkan anak-anak muda mereka justru berupaya mengeliminirnya. Karmodo menjalin cinta dengan Lien Nio, anak hibrid Bian Biau dengan perempuan Jawa bernama Kartinah. Meskipun hubungannya mendapat banyak rintangan akhirnya mereka dapat bersatu. Karsini adalah perempuan Jawa yang menolak stereotip bahwa laki-laki Tionghoa merendahkan perempuan Jawa dengan hanya memosisikannya sebagai gundik. Ia percaya pada cinta dan niat baik Ing Liem yang ingin menikahinya secara resmi dan melebur ke dalam masyarakat Jawa dengan jalan pindah agama. Cinta Karsini pada Ing Liem mampu merobohkan sekat etnis. Karsini menganggap orang tuanyalah yang kolot dan ketinggalan zaman (hlm. 21).

Lien Nio dan Ing Liem menentang ekseklusivisme yang dipaksakan oleh orang tuanya dengan cara menolak pernikahan sesama etnis Tionghoa. Mereka juga digambarkan menentang prasangka yang keliru bahwa etnis Jawa hanya bangsa kuli dan jongos sehingga tidak layak dijadikan teman apalagi pasangan hidup. Untuk menentang pandangan orang tuanya, mereka justru memilih pasangan hidup dari kalangan etnis Jawa. Sebagai generasi muda Tionghoa, yang lahir di Indonesia, mereka merasa telah menjadi bagian dari bangsa Indonesia bersama-sama dengan etnis Jawa dan etnis-etnis lainnya. Jika Ing Liem rela berpindah ke agama Islam untuk 
membaur ke dalam masyarakat Jawa, Lien Nio dengan senang hati menggunakan busana Jawa, nama Jawa, dan berbahasa Jawa. Mereka anakanak muda Tionghoa yang menganggap bumi Indonesia sebagai tanah kelahirannya sehingga merasa bukan sebagai orang asing dan tidak berbeda dengan etnis Jawa sebagai sesama bangsa Indonesia. Mereka ingin membaur dengan etnis Jawa dan berusaha mengubah perilaku kelompoknya yang masih merasa sebagai orang Cina. Oleh karena itu, mereka dapat diterima oleh orang-orang Jawa (hlm. 22).

Pembauran melalui pernikahan antaretnis akan melahirkan anak-anak hibrid yang diharapkan dapat mengatasi jarak sosial. Anak hibrid ini digambarkan memiliki pandangan yang lebih inklusif dan dapat mengatasi sekat etnis, seperti Lien Nio yang mampu keluar dari stereotip dan prasangka negatif kelompoknya dalam memandang etnis Jawa (hlm. 13-14). Meskipun sejak kecil Tan Bian Biau berusaha memutuskan hubungannya dengan keluarga ibunya, tetapi Lien Nio tetap mendapat pengetahuan budaya Jawa dari ibunya sehingga tidak menafikan darah Jawa yang mengalir di tubuhnya, bahkan ia terlihat "lebih njawani ketimbang nyinani" "lebih bersifat Jawa daripada Cina'. Ia sangat menghargai orang-orang Jawa sebagai leluhurnya. Dengan identitas seperti itu, Lien Nio dapat diterima oleh etnis Jawa tanpa prasangka dan curiga. Ketika ayahnya meninggal, ia ditunjuk sebagai ahli warisnya. Ia bersedia melanjutkan usaha yang sudah dibangun ayahnya, tetapi menolak cara berbisnisnya yang menghalalkan segala cara. Ia berharap pejabat-pejabat Jawa juga bersikap jujur sehingga peluang etnis Tionghoa menggunakan cara menyuap untuk mencapai tujuan tidak akan berhasil dan dengan sendirinya akan mengikis stereotip etnis Tionghoa sebagai penyuap.

Direstuinya hubungan percintaan (perkawinan) Karmodo dengan Lien Nio dan Ing Liem dengan Karsini dalam novel ini menggambarkan optimisme pengarang terhadap solusi jalan tengah untuk menciptakan hubungan yang lebih baik antara etnis Jawa dan Tionghoa karena perkawinan tidak hanya memungkinkan hubungan yang erat antardua orang, tetapi juga akan mendekatkan atau mengeratkan hubungan dua keluarga sehingga dapat mengurangi jarak sosial (Sumarto, 1993:144). Tawaran solusi jalan tengah ini juga dipertegas dengan pencitraan Yuk Lien Nio, anak hibrid hasil percampuran etnis Tionghoa dan Jawa, yang digambarkan dengan simpatik sebagai pahlawan dan penyelamat di dalam TTJ karena dapat mengatasi persoalan rasial. Yuk Lien Nio yang hibrid menjadi gambaran manusia ideal dan seimbang, melihat kedua etnis leluhurnya tidak dengan stereotip dan prasangka negatif hingga Karmodo pun akhirnya minta maaf atas prasangka negatifnya pada orang-orang Tionghoa. Pesan arif novel ini pun disampaikan melalui Yuk Lien Nio (hlm. 99).

Pengarang TTJ optimis akan terjadinya pembauran melalui generasi muda kedua etnis yang tidak mau lagi tersekat dalam ruang-ruang sempit etnis, seperti orang tua mereka dengan mengedepankan perasaan sebagai sesama orang Indonesia. Saling mempengaruhi bukanlah hal yang buruk karena tidak ada satu bangsa pun di dunia yang dapat mempertahankan "kemurniannya" selamanya. Saling curiga dan benci juga tidak akan membawa manfaat, lebih baik bekerja sama. Novel ini memberi harapan baik bahwa hubungan yang damai dan harmonis bukan satu hal yang mustahil terwujud jika kedua belah pihak dapat saling menghargai dan menghilangkan kecurigaan. Optimisme ini patut diapresiasi dan barangkali bukan hal yang berlebihan mengingat dalam sejarah hubungan etnis Jawa dan Tionghoa di Pulau Jawa dengan segala dinamika pasang surutnya sudah terbukti dapat membaur, hidup rukun, dan damai.

\section{E. PENUTUP}

Sastra Jawa yang ditulis dengan media bahasa Jawa dan memiliki pembaca terbatas pada orang-orang yang mengerti bahasa Jawa ternyata tidak hanya berkutat dengan persoalan-persoalan di dalam kelompok 
etnisnya semata, tetapi juga menaruh kepedulian terhadap berbagai persoalan yang dihadapi bangsa Indonesia, salah satunya masalah yang menyangkut hubungan antaretnis. Dengan demikian, sesungguhnya sastra daerah (Jawa) juga telah memberikan kontribusi dalam rangka membangun dan mengelola hubungan antaretnis di Indonesia yang sering kali tidak harmonis dan menimbulkan konflik bernuansa SARA dengan menawarkan satu alternatif solusi. Alternatif solusi yang ditawarkan pengarang itu dapat menjadi bahan renungan untuk melihat bagaimana masyarakat menghadapi persoalan yang tidak jauh berbeda dalam kehidupan sehari-harinya.

\section{DAFTAR PUSTAKA}

A.S. Marcus dan Pax Benedanto. (Ed.). 2000. Kesastraan Melayu Tionghoa dalam Kebangsaan Indonesia. Jilid I. Jakarta: Kepustakaan Populer Gramedia Bekerja Sama dengan Yayasan Adikarya IKAPI dan The Ford Foundation.

Adam, Asvi Warman.2002. "Tionghoa di Kanvas Raksasa”. Makalah pada Diskusi Akbar yang Diselenggarakan oleh Perhimpunan INTI di Jakarta pada tanggal 27 April.

Carey, Peter. 2008. Orang Cina, Bandar Tol, Candu, dan Perang Jawa: Perubahan Persepsi tentang Cina 1755-1825. Jakarta: Komunitas Bambu.

Christanty, Linda. 1994. "Nyai dan Masyarakat Kolonial Hindia Belanda". Dalam Prisma No. 10/XXIII, Oktober, hlm. 22-30 1994.

Damono, Sapardi Djoko. 1999. Politik Ideologi dan Sastra Hibrida. Jakarta: Pustaka Firdaus Bekerja Sama dengan Yayasan Adikarya IKAPI dan The Ford Foundation.

Esmiet. 1977. Tunggak-Tunggak Jati. Jakarta: Pustaka Jaya.
Faruk, Bakdi Soemanto, dan Bambang Purwanto. 2001. Perlawanan Atas Diskriminasi Rasial-Etnik: Konteks Sosial-Ideologis Kritik Sastra Tionghoa Peranakan. Magelang: Indonesiatera.

Hutomo, Suripan Sadi. 1978. "Pribumi dan Nonpribumi dalam Sastra Indonesia dan Daerah" dalam Surabaya Post, Senin, 27 Maret 1978.

Hutomo, Suripan Sadi dan Setya Yuwana Sudikan. 1988. "Sastra Jawa Dewasa Ini: Tema Pembauran dan Pembauran Bangsa" dalam Problematik Sastra Jawa: Sejumlah Esai Sastra Jawa Modern. Surabaya: Fakultas Pendidikan Bahasa dan Seni, hlm. 3148.

Joe Lan, Nio. 1962. Sastra IndonesiaTionghoa. Jakarta: Gunung Agung.

Lohanda, Mona. 2001. The Capitan Cina of Batavia, 1837-1942. Jakarta: Djambatan Bekerja Sama dengan KITLV.

Salmon, Claudine. 1985. Sastra Cina Peranakan dalam Bahasa Melayu. Terjemahan Dede Oetomo. Jakarta: Balai Pustaka. .1999. "Fiksi Etnografis dalam Kesusasteraan Melayu Peranakan". Dalam Panggung Sejarah: Persembahan kepada Prof. Dr. Denys Lombard. (Ed.) Henri Chambert-Loir dan Hasan Muarif Ambari. Jakarta: Ecole Francaise d'Extreme Orient, Pusat Arkeologi Nasional, Yayasan Obor Indonesia, hlm. 365-381.

Setiono, Benny G. 2002. "Etnis Tionghoa adalah Bagian Integral Bangsa Indonesia". Makalah pada Diskusi Akbar yang Diselenggarakan oleh Perhimpunan INTI di Jakarta pada tanggal 27 April.

Soeprapto, Y. Sarwono. 1993. "Rasialisme dalam Sastra Jawa Modern" dalam Wawasan Sastra Jawa Modern. (Ed.) 
Poer Adhi Prawoto. Bandung: Widati, Sri et al.2001. Ikhtisar Perkembangan Angkasa, hlm. 55-58.

Sumardjo, Jakob.1979. Masyarakat dan Sastra Sastra Jawa Modern Periode Kemerdekaan. Yogyakarta: Kalika. ndonesia. Yogyakarta: CV. Nur Cahaya.

Sumarto, Kunanto. 1993. Pengantar Sosiologi. Jakarta: Lembaga Penerbitan Fakultas Ekonomi Universitas Indonesia. 